ABDI: Jurnal Pengabdian dan Pemberdayaan Masyarakat ISSN: 2656-369X (Print), 2684-8570 (Online)

Volume 2 No. 1, Juni 2020

http://abdi.ppj.unp.ac.id/index.php/abdi

Email: abdi@ppj.unp.ac.id

DOI: https://doi.org/10.24036/abdi.v2il.29

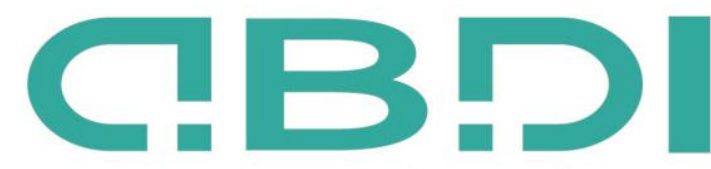

ABDI: JURNAL PENGABDIAN DAN PEMBERDAYAAN MASYARAKAT

\title{
Pelatihan Penyusunan Soal Bahasa Indonesia Berorientasi HOT'S untuk Guru SMP dan SMA
}

\author{
Dian Eka Chandra Wardhana ${ }^{1}$, Ria Ariesta ${ }^{2}$, Sarwit Sarwono ${ }^{3}$ \\ ${ }^{1,3}$ Magister Pendidikan Bahasan Indonesia, Universitas Bengkulu \\ ${ }^{2}$ Program Studi Pendidikan Bahasan Indonesia, Universitas Bengkulu \\ Email : dec.wardhana@unib.ac.id, riaariesta@yahoo.com, sarwitsudiro@gmail.com
}

\begin{abstract}
Abstrak
Guru Bahasa Indonesia SMP/SMA abad 21 adalah guru yang dapat merumuskan soal-soal yang dapat mengembangkan kecakapan bernalar siswa (HOTs), namun sampai saat ini soal yang dirumuskan masih berkisar pada soal LOTs (C1, C2, dan C3). Dengan demikian perlu pelatihan penyusunan soal Bahasa Indonesia yang berorientasi HOT's. Metode pelatihan yang digunakan adalah model proses program pelatihan yang dikemukan oleh Leagens. Model ini berupa model instruksional yang memuat komponen situasi, masalah, tujuan, dan cara untuk mencapai tujuan atau $S-M-T-C$. Data kegiatan pengabdian ini diambil dengan pre test dan post test dengan instrumen soal HOTs yang berbentuk essay. Analisis data pengabdian dianalisis dengan uji T. Hasil pelatihan yang diperoleh adalah ada perubahan tingkah laku guru (subyek) pelatihan yang dibuktikan dengan hasil analisis data yang dikumpulkan dengan uji T. Hasil pelatihan adalah rata-rata nilai jawaban intrumen oleh responden pada pretest sebesar 46,63 lebih rendah jika dibandingkan dengan rata-rata nilai jawaban intrumen pada posttest oleh responden yaitu 72,60. Hasil uji t menunjukkan bahwa nilai $P(T<=t)$ one-tail sebesar 0,00. Hal tersebut menunjukkan bahwa nilai pretest berbeda nyata dengan nilai posttest karena nilai $P(T<=t)$ one-tail lebih rendah dari taraf $5 \%(0,05)$.
\end{abstract}

Kata kunci : Guru, HOTs, Pengabdian, Kecakapan, Nalar, Tingkat tinggi

\section{Abstract}

Indonesian Language Teachers at Junior/Senior High School in 21 st century are teachers who are able to formulate the questions in order to develop the students' ability to think logically that is called Higher Order Thinking (HOT), but the questions that have formulated still in level Lower Order Thinking (LOT) such as C1, $C 2$, and C3. Due to this problem, it is needed the training to arrange the questions for the Indonesian Language subject that is oriented to HOT. The method of training used was following a training process model that is proposed by Leagens. It is an instructional model that contains some components such as situational, problems, purpose, and the way to reach the purpose or is known as term S-M-T-C. The data of training was taken from pre-test and post-test by using the instruments of HOTs questions in essay form. The analysis of data was using t-test analysis. The result of training showed the changing of teachers' attitude (subject) during training that is proved by the result of t-test analysis. As a result, the average score of respondents' answers based on the instrument in the pre-test was 46,63 lower than the average score in the post-test that is 72,60. Then, the result of the t-test showed that the P-value or $P(t \leq t)$ on-tail was 0,00. It means that the score for the pre-test was significantly different from the score for the post-test because $P(t \leq t)$ one-tail is lower from the significance score of $5 \%(0,05)$.

Keyeords : High Level, HOTs, Teachers, Training, Skills, Reasoning

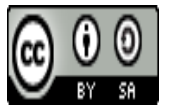

Received: 5 Desember $2019 \quad$ Revised: 13 Januari $2020 \quad$ Available Online: 15 Januari 2020




\section{Pendahuluan}

Pengamatan terus menerus selama 3-5 tahun terakhir, ditandai dengan suatu kecemasan terhadap aspek penilaian mutu akademik siswa. Kecemasan ini beralasan karena di era 05.0 guru masih melakukan kegiatan penyusunan soal-soal yang berkisar pada C1, C2, dan C3. Sedangkan komponen soal yang bernuansa reflektif ( $\mathrm{C} 4, \mathrm{C} 5$ dan $\mathrm{C} 6)$ tampak masih belum secara signifikan digunakan. Padahal komponen soal dengan nuansa tersebut mampu mengembangkan kecakapan berpikir kritis dan kreatif. Pengamatan berlanjut pada nuansa deskriptif menuju era yang kritis, kreatif, kolaboratif, inovatis, dan komunikatif. Hasil pengamatan tersebut didiskusikan dengan tim pengabdi yang mempunyai kesamaan pandangan. Hasil pengamatan ini diperkuat dengan fakta yang terjadi di lapangan bahwa kebutuhan pembangunan abad 21 di Provinsi Bengkulu pada khususnya, dan Indonesia pada umumnya sudah selaras dengan pembangunan yang meliputi pembangunan fisik, mental dan sosial spiritual, di ranah global, namun masih perlu diperkuat dengan pembangunan di ranah mental dan sosial spiritual karena kebutuhan dunia milenial dan pembangunan abad 21 sudah diambang pintu. Literasi media adalah pendidikan yang mengajari khalayak media agar memiliki kemampuan menganalisis pesan media, memahami bahwa media memiliki tujuan komersial/bisnis dan politik sehingga mereka mampu bertanggungjawab dan memberikan respon yang benar ketika mendapatkan informasi dari media. (Fernandes, R., Vidya Putra, E., \& Muspita, R, 2019)

Begitupun Program Magister S-2 Pendidikan Bahasa Indonesia FKIP UNIB mempunyai kewajiban melaksanakan kegiatan Tri Dharma Pendidikan Tinggi, telah terlibat aktif dalam pembangunan karakter bangsa (nation character building), termasuk pembangunan peningkatan kompetensi guru sejak memperoleh ijin pendirian prodi tahun 2007. Oleh karena itu, semua kegiatan di Program Magister S-2 Pendidikan Bahasa Indonesia FKIP Unib ini, berpeluang untuk ikut berperan serta mempersiapkan sumber daya manusia, khususnya guru agar guru mempunyai kompetensi dan daya saing tinggi dalam menghadapi situasi dan kondisi regional, nasional maupun global. Kondisi ini merupakan salah satu perwujudan visi dan misi Program Magister S-2 untuk kokoh menapakkan kakinya menjadi Program Studi yang Unggul di dalam mengimplementasikan konsep-konsep baru di masyarakat. Terutama masyarakat di selingkung kampus.

Selanjutnya, Rejang Lebong merupakan salah satu daerah yang secara geografis terletak di daerah hutan tropis, dan sekitar $85 \mathrm{~km}$ dari Program Magister S-2 Pendidikan Bahasa Indonesia FKIP Unib. Daerah ini merupakan daerah yang menjadi sasaran pengembangan pembangunan di era global, karena layak dijadikan sasaran kegiatan pengabdian. Di samping itu, ketahanan masyarakat di daerah ini perlu ditingkatkan melalui jaringan sosial lokal, regional, nasional dan global agar terkait dengan pembangunan dan pengembangan potensi manusia global untuk menempatkan manusia sebagai subjek sekaligus objek pembangunan (people center development). Pembangunan ini melalui pembangunan dan pengembangan masyarakat yang bersifat sistematis, komprehensif, dan berkesinambungan. Oleh karena itu, langkah awal keterlibatan program studi di daerah ini melalui kegiatan pengabdian kepada masyarakat menjadi sangat penting.

Hal ini diperkuat dengan studi pendahuluan di 4 sekolah yang berada di kota Rejang Lebong. Perumusan soal-soal di 4 sekolah tersebut (dua sekolah Negeri dan dua sekolah Swasta), soal ujian buatan Guru maupun soal ujian sekolah masih dirumuskan pada soal dengan jenjang kognitif seputar C1, C2 dan C3. Hal ini dipertegas oleh Guru senior yang sekarang menjadi Kepala Dinas Rejang Lebong, bahwa guru-guru masih mempersepsi bahwa soal dengan HOTs merupakan soal yang sulit. Dukungan senada didapat dari hasil penelitian penilaian berbahasa Indonesia. Hasil penelitian tersebut mengatakan bahwa soal-soal HOTs belum dirumuskan secara signifikan untuk meningkatkan kompetensi bernalar siswa. Oleh karena itu, dapat dikatakan bahwa situasi ini menjadi salah satu penyebab gagalnya berbagai peningkatan kompetensi yang harus dimiliki siswa (Al-Maamari, 2016). Karakter seorang anak dapat dikembangkan melalui berbagai soal yang sering diberikan guru kepada anak, baik soal yang mengutamakan pendeskripsian sebuah fenomena maupun soal-soal reflektif terhadap fenomena yang berkembang disekitar mereka (Kurniati, Harimukti, \& Jamil, 2016). Berdasarkan pada fenomena tersebut, kegiatan pengabdian ini dilakukan dengan rumusan bagaimanakah effektivitas materi pelatihan penyusunan soal-soal Bahasa Indonesia yang berorientasi 
HOT's untuk Guru SMP/SMA guna mengembangkan kecakapan bernalar siswa di Rejang Lebong Propinsi Bengkulu?

Di samping itu, effektivitas materi dirumuskan secara khusus karena fenomena yang berkembang saat ini adalah mendesaknya kebutuhan penyikapan terhadap data atau informasi yang berkembang di sekitar siswa. Secepat kilat para siswa dapat memenuhi kebutuhan informasi yang mereka perlukan, dan dapat mengembangkan kecakapan bernalarnya, sehingga siswa akan mampu memanfaatkan informasi tersebut untuk salah satu kebutuhan bagi pengembangan intelektual dan keterampilan siswa dalam berpikir kritis.

Kegiatan berpikir kritis ini di dalam pembelajaran yang dilakukan selama ini sudah dikembangkan namun belum maksimal. Berdasarkan hasil pengamatan yang dilakukan secara terus menerus sejak 2017 sampai 2019, menunjukkan adanya kecenderungan bahwa pembelajaran di tingkat SMP/SMA maupun perguruan tinggi, masih didominasi oleh pembelajaran untuk menyampaikan informasi sehingga pembelajar hanya memperoleh kemampuan sebatas menguasai dan memahami pengetahuan. Sehingga ada pemikiran hal inilah yang menyebabkan ranking Indonesia dalam kurun 3 tahun terakhir menurut hasil penelitian PISA menurun.

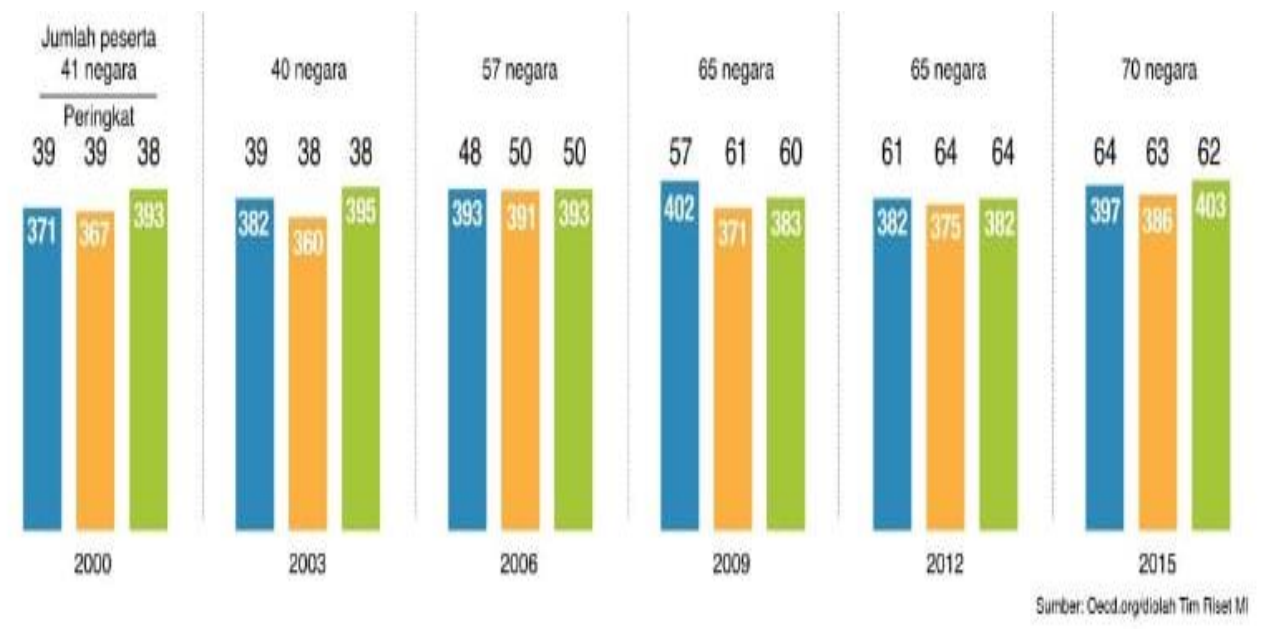

Gambar 1. Laporan Penelitian PISA 2018 (Winahyu, 2019)

Berdasarkan pada fenomena yang dilaporkan PISA 2018 (Winahyu, 2019), dan merujuk pada fakta kegiatan pembelajaran Bahasa Indonesia di sekolah sebagai sarana pengembangan kegiatan berpikir kritis dan kreatif yang diwujudkan dalam kegiatan implementasi berbagai informasi teks (literasi) fiksi maupun non fiksi yang berkembang di masyarakat, maka pengetahuan tentang keberadaan teks tersebut seyogjanya dapat dimanfaatkan di dalam pemenuhan kebutuhan kesejahteraan siswa sesuai dengan fungsi masing masing teks di dalam kehidupan keseharian mereka. Dampak yang berkembang atas keberadaan matapelajaran bahasa Indonesia di sekolah adalah berkembangnya keterampilan berbahasa dan berpikir kritis dan kreatif. Matapelajaran ini sangat membantu siswa di dalam mengaplikasikan kecakapannya dalam menjawab soal. Soal-soal matapelajaran Bahasa Indonesia dirumuskan untuk mengukur kemampuan berbahasa dan berpikir dengan menggunakan bahasa Indonesia. Oleh karena itu, kegiatan pengabdian ini sangat memungkinkan melibatkan kerjasama antara dosen dengan pihak dinas Dikbud dan Guru. Keterlibatan pihak pihak tersebut sebagai bagian dari pelaksanaan pengabdian ini, khususnya dalam merancang konsep dan instrumen yang dapat digunakan untuk mengukur kecakapan bernalar siswa (SMP dan SMA) dengan soal-soal matapelajaran Bahasa Indonesia berbasis HOT's. Kecakapan ini akan lebih terlihat konkrit karena sebagian besar guru sudah sering merumuskan soal-soal bahasa Indonesia sebelumnya dan membantu siswa di dalam menjawab soal-soal UN di sekolah.

Berpikir kritis termasuk ke dalam berpikir ke tingkat yang lebih tinggi (HOT) (Brookhart, 2010). HOT didefinisikan dalam tiga istilah, yaitu transfer, berpikir kritis, dan pemecahan masalah.

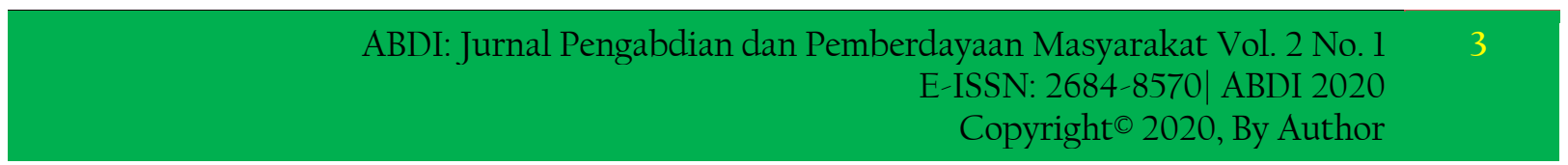


Berpikir kritis adalah "reasonable, reflecting thinking that is focused on deciding what to believe or do". Lebih lanjut berpikir kritis mencakup "reasoning, questioning and investigating, observing and describing, comparing and connecting finding complexity, and exploring viewpoints, yang berarti bahwa berpikir kritis sebagai "seni berpikir", yang meliputi penalaran, mempertanyakan, dan menyelidiki, mengamati dan menggambarkan, membandingkan dan menghubungkan, menemukan kompleksitas, dan menjelajahi sudut pandang (Norris, \& Ennis, 1989).

Berpikir kritis merujuk pada: a) kesadaran terhadap seperangkat pertanyaan kritis yang berkaitan, b) kemampuan bertanya dan menjawab pertanyaan kritis dengan cara tertentu, c) keinginan untuk menggunakan pertanyaan krisis secara aktif. Kegiatan menanya dan menjawab merupakan salah satu bentuk kegiatan berpikir kritis. Sedangkan tinjauan untuk tujuan belajar, pertanyaan yang dibuat mengacu pada taksonomi Bloom. Menurut Bloom terdapat enam level proses kognitif, yaitu "knowledge, comprehension, application, analysis, synthesis, evaluation"(Browne, N. \& Stuart, 2015). Pendapat Bloom ini dikritisi dan direvisi bahwa pengetahuan terbagi dua dimensi, yaitu domain pengetahuan dan domain proses kognitif. Domain pengetahuan terbagi ke dalam empat tipe pengetahuan, yaitu: faktual, konseptual, prosedural, dan metakognitf. Lebih lanjut dijelaskan bahwa pengetahuan faktual berkaitan dengan "... basic elements students must know to be acquainted with a discipline or solve a problem in it," pengetahuan konseptual berkaitan dengan "... the interrelationships among the basic elements within a larger structure that enable them to function together," pengetahuan prosedural berkaitan dengan "... how to do something, methods of inquiry, and criteria for using skills, algorithms, techniques, and methods," pengetahuan metakognitif berkaitan dengan "... knowledge of cognition in general as well as awareness and knowledge of one's own cognition". Sedangkan, domain proses kognitif terdapat enam tipe berpikir, yaitu mengingat berkaitan dengan "... retrieving relevant knowledge from long-term memory”, memahami berkaitan dengan “... constructing meaning from instructional messages, including oral, written, and graphic communication", menerapkan berkaitan dengan "... carrying out or using a procedure in a given situation", menganalisis berkaitan dengan "... breaking material inti constituent parts and determining how parts related to one another and to overall structure or purpose, menilai berkaitan dengan "... making judgements based on criteria and standards", berkreasi berkaitan dengan "... putting elements together to form a coherent or functional whole, and reorganizing elements into a new pattern or structure" (Anderson, L. W., D.R, Krathwohl., P.W, Airasian., K.A, Cruikshank., R.E, Mayer., \& P.R, 2001).

Oleh karena itu berdasarkan fenomena tersebut, kegiatan pengabdian dengan topik pelatihan menulis soal HOT untuk guru menjadi penting. Hal ini dapat terlaksana dengan melibatkan kerjasama antara dosen (Perguruan Tinggi) dengan pihak dinas Dikbud dan Sekolah. Keterlibatan pihak pihak tersebut sebagai bagian dari pelaksanaan pengabdian ini, khususnya dalam merancang konsep dan instrumen yang dapat digunakan untuk mengukur kecakapan bernalar siswa (SMP dan SMA) dengan soal-soal matapelajaran Bahasa Indonesia berbasis HOT's. Kecakapan ini akan lebih terlihat konkrit karena sebagian besar guru sudah sering merumuskan soal-soal bahasa Indonesia sebelumnya dan membantu siswa di dalam menjawab soal-soal UN di sekolah.

\section{Metode Pelaksanaan}

Metode yang digunakan dalam pelatihan ini merupakan metode yang diturunkan dari model proses program pelatihan yang dikemukan oleh Leagens (Leagan, 1962). Model Leagens merupakan salah satu dari beberapa model proses program pelatihan. Sebagaimana model-model lainnya, model ini pada hakikatnya berupa model instruksional yang memuat komponen-komponen situasi, masalah, tujuan, dan cara untuk mencapai tujuan atau yang sering dikenal dengan S-M-T-C. Ada lima langkah dalam proses perencanaan program penyuluhan ini adalah sebagai berikut: (1) Perumusan keadaan dan masalahnya. Pada tahap ini dilakukan analisis situasi, berdasar analisis situasi yang ditemukan ada fakta-fakta yang mendukung diperlukannya kegiatan pengabdian tersebut. Fakta yang dimaksudkan hasil laporan PISA 2018, yang mengatakan bahwa kemmapuan membaca, literasi dan matematika siswa Indonesia yang berusia 15 th menurun (tiga tahun terakhir), hal ini didukung dengan kegiatan observasi yang mengatakan bahwa soal bernuansa HOT sulit sehingga ada 
kecenderungan, guru menulis soal hanya berkisar pada jenjang kognitif $\mathrm{C} 1, \mathrm{C} 2$ dan $\mathrm{C} 3$. Dukungan lain juga tampak dari hasil-hasil penelitian terdahulu. (2) Pemecahan masalah dalam kegiatan ini dirumuskan dalam kegiatan tujuan pengabdian yang sedang dilaksanakan, yakni pelatihan penyusunan HOT untuk guru SMP/SMA guna mengembangkan keterampilan berpikir kritis dan reflektif siswa. Dan, (3) Selanjutnya, tahap kegiatan pembelajaran. Di dalam kegiatan pembelajaran pada tahap ini dilaksanakan dengan metode eklektik dan teknik diskusi, ceramah dan penggunaan LCD . Berdasarkan metode dan teknik yang digunakan, maka tercipta kesempatan pelaksanan kegiatan pengabdian. Dengan demikian pada tahap ini ada situasi belajar dan mengajar guna terciptanya situasi komunikasi yang interaktif dan merangsang tindakan belajar dalam kelompok dan interpersonal. (4) Tahap keempat adalah tahap evaluasi. Pada tahap ini evaluasi kegiatan perlu dilakukan guna merumuskan suatu perencanaan kerja untuk kegiatan pengabdian yang akan datang agar dapat dilakukan secara lebih baik. Proses evaluasi di dalam kegiatan pengabdian ini menggunakan panduan evaluasi dengan 5 pertanyaan diantaranya (a) bagaimanakah kondisi ruangan tempat pengabdian, (b) apakah pelaksanaan pengabdian pada saat ini ada transpor ?, (c) Bagaimana kualitas snack dan makan siang kegiatan?, (d) bagaimana kualitas nara sumber ketika menyampaikan materi? (e) Apakah ada sertifikat yang disiapkan panitia? Kegiatan evaluasi dilakukan secara sederhana dan informal kepada peserta secara acak. (5) Tahap terakhir adalah tahap rekonsiderasi. Pada tahap ini terumuskan suatu upaya perbaikan untuk kegiatan pengabdian tahun depan. Hal ini sangat diperlukan agar kegiatan pengabdian yang akan dilakukan pada tahun tahun mendatang merupakan suatu rangkaian proses yang berlinanjut, karena ada perubahan perilaku subyek peserta pengabdian.

\section{Hasil dan Pembahasan}

\section{Tempat Pengabdian}

Tempat kegiatan di SMPN 1 Rejang Lebong seperti yang direkomendasikan oleh Kepala Dinas Rejang Lebong. Pelaksanaan pengabdian pada hari Sabtu, tanggal 9 November 2019. Foto tempat kegiatan pengabdian dâpat dibaca pada gambar 1. Tempat pengabdian beralamat di kota curup atau kota Rejang Lebong.

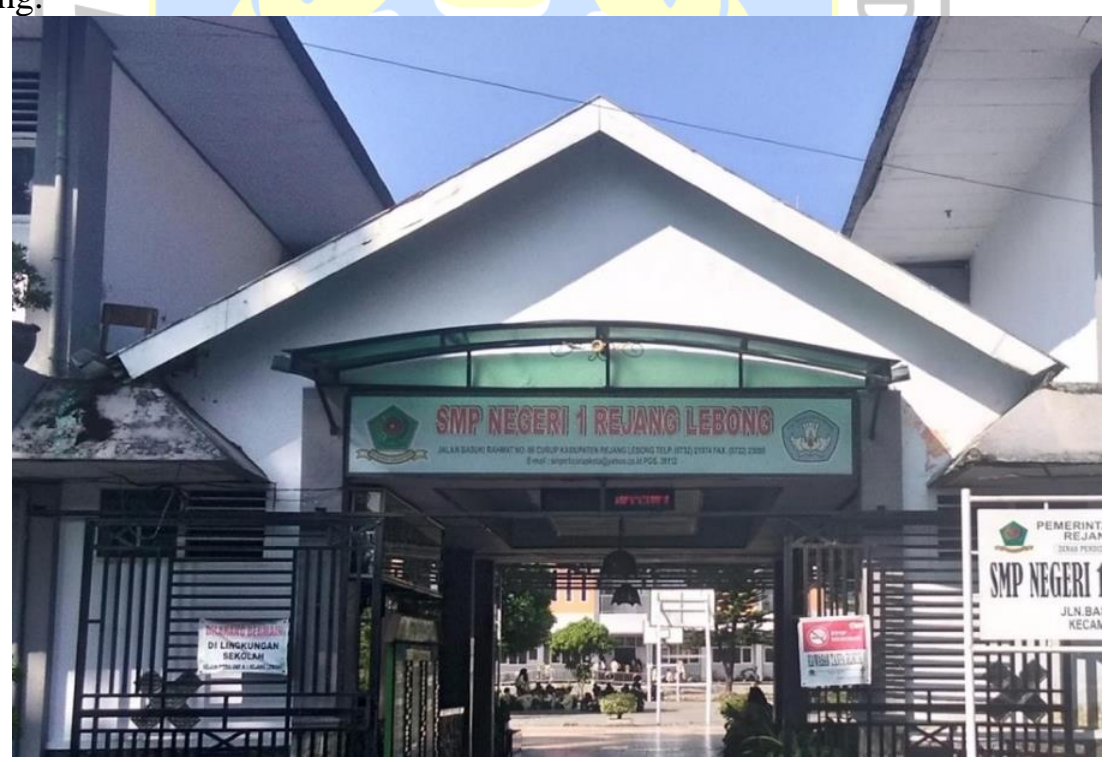

Gambar 2. Sekolah Tempat Kegiatan Pengabdian

Sekolah tempat pengabdian ini letaknya yang sangat strategis. dan mudah dijangkau oleh semua guru peserta kegiatan pengabdian. Perlu diketahui, sekolah ini merupakan tempat mangkal kegiatan yang diselenggarakan oleh MGMP Bahasa Indonesia SMP, namun pada saat pelaksanaan pengabdian seluruh peserta dari MGMP Bahasa Indonesia SMA bergabung di tempat yang sama. Di samping itu pada saat kegiatan pengabdian berlangsung di tempat yang sama siswa dari seluruh SMPN Rejang Lebong sedang berkumpul untuk mengadakan kegiatan temu karya V, yang rutin 
dilaksanakan secara berkala (satu bulan sekali) di tempat yang sama. Oleh karena itu dapat dibayangkan suasana sekolah yang sangat ramai namun sejuk sekali setelah masuk ke ruang pengabdian yang ada di lantai 2 (Ruang Pentas Seni) sekolah. Tempat pelaksanaan di ruang seni tersebut sudah tertata rapi dan mengesankan suasana yang sangat representatif sebagai tempat kegiatan pengabdian. Rencana pelaksanaan kegiatan pengabdian diikuti oleh guru SMP dan SMA sebanyak 50 orang dan staf dari Diknas 2 orang. Ruang dengan meja yang standard, bertaplak dan pencahayaan yang cukup. Ada papan tulis dan media LCD.

\section{Pelaksanaan Kegiatan}

Pelaksanaan kegiatan pengabdian dihadiri oleh Kepala Dinas Pendidikan dan Kebudayaan Rejang Lebong (Gambar 2), dan pada hari $\mathrm{H}$ pelaksanaan pengabdian dihadiri oleh Kepala Bidang Ketenagaan Dinas Pendidikan dan Kebudayaan Rejang Lebong (Erwan Zuganda, S.H) bersama dua stafnya. Kegiatan dibuka secara resmi dengan pewara tim pengabdi (Ibu Ria Ariesta), selanjutnya dilakukan foto bersama dan pelaksanaan pre test. Pesan menarik diucapkan oleh Erwan Zuganda, S.H, bahwa kegiatan pengabdian ini sangat penting karena sudah saatnya guru berubah. Berubah merumuskan soal-soal deskriptif menjadi soal yang bernuansa kritis dan reflektif. Selanjutnya dilaksanakan kegiatan pengabdian.

Pelaksanaan kegiatan pengabdian oleh tim pengabdi dari Program Magister Pascasarjana Pendidikan Bahasa Indonesia dilaksanakan dengan semangat tinggi, karena kondisi cuaca yang cerah, ditambah dengan kondisi ruangan yang representatif sangat bersih, meja tertata rapi, pencahayaan cukup, tersedia LCD sehingga subyek pengabdian dapat memanfaatkan laptop untuk merealisasikan materi kegiatan pengabdian. Ketiga tim pengabdi secara antusias melaksanakan diskusi dan secara sambung menyambung saling mengisi menyampaikan materi. Pelaksanaan pengabdian menggunakan metode eklektik, dan diakhiri dengan menyebarkan lembar tanyaan (post test), serta daftar tanyaan evaluasi kegiatan (kepada panitia pelaksana, 3 orang dan peserta 3 orang), dengan tujuan mencari masukan untuk kegiatan pengabdian di periode yang akan datang. Guru-guru diberikan pre-test dan post-test untuk melihat kemampuan awal dan sebagai evaluasi kemampuan guru sebelum dan sesudah pemberian materi dan pelatihan. (Muspita, R., Efrina, E., Fernandes, R., Putera, A. S., \& Mahdi, A., 2019)

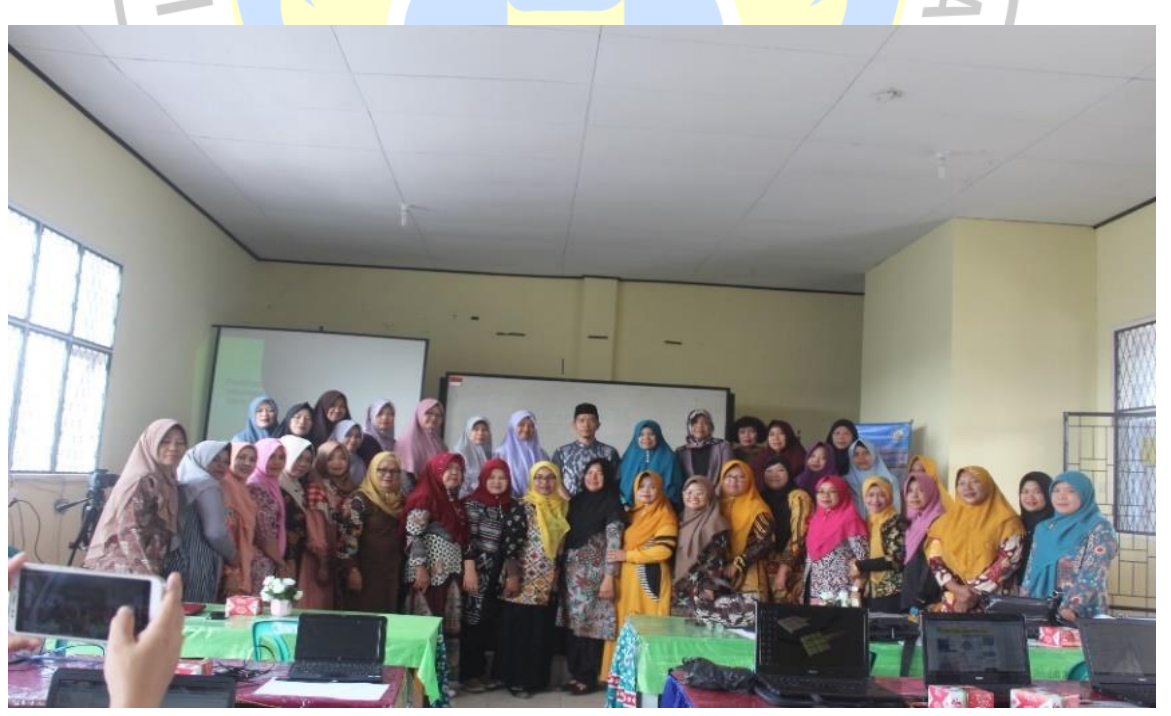

Gambar 3. Foto bersama Kabid Ketenagaan, Tim Pengabdi dan subyek pengabdian

Kegiatan evaluasi dilakukan untuk melihat sejauh mana pelatihan itu dapat dilaksanakan sesuai dengan model pelatihan yang dilakukan. Materi evaluasi meliputi evaluasi pelaksanaan program. Evaluasi yang dimaksud adalah evaluasi model pelatihan, yang meliputi evaluasi persiapan. Evaluasi ini dimaksudkan untuk mengetahui seberapa jauh persiapan yang telah dilakukan oleh panitia. Hal-hal yang dievaluasi sebagaimana yang tersebut pada tahap persiapan. Melalui kegiatan ini akan dapat diputuskan apakah pelatihan siap untuk dilaksanakan atau tidak. Evaluasi Pelaksanaan (proses), hal-

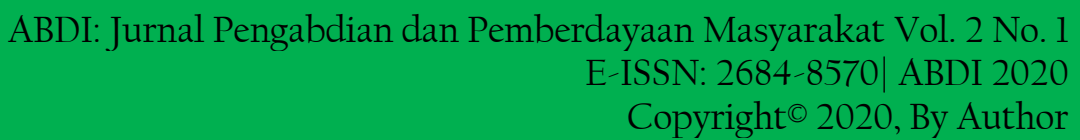


hal yang dievaluasi pada tahap pelaksanaan pelatihan meliputi: (Evaluasi Peserta, menyangkut: (1) penguasaan materi ; (2) kedisiplinan; (3) ketertiban; dan (4) sikap); Evaluasi Fasilitator, menyangkut (penguasaan materi ; kesesuaian materi dengan topik bahasan yang disampaikan; ketepatan metode yang digunakan; kesesuaian media yang digunakan; penampilan; peggunaan bahasa); Evaluasi Penyelenggaraan, menyangkut kebersihan ruang pelatihan, akomodasi dan konsumsi, serta pelayanan Panitia. Pelaksanaan kegiatan pengabdian dapat di lihat pada Gambar 4.

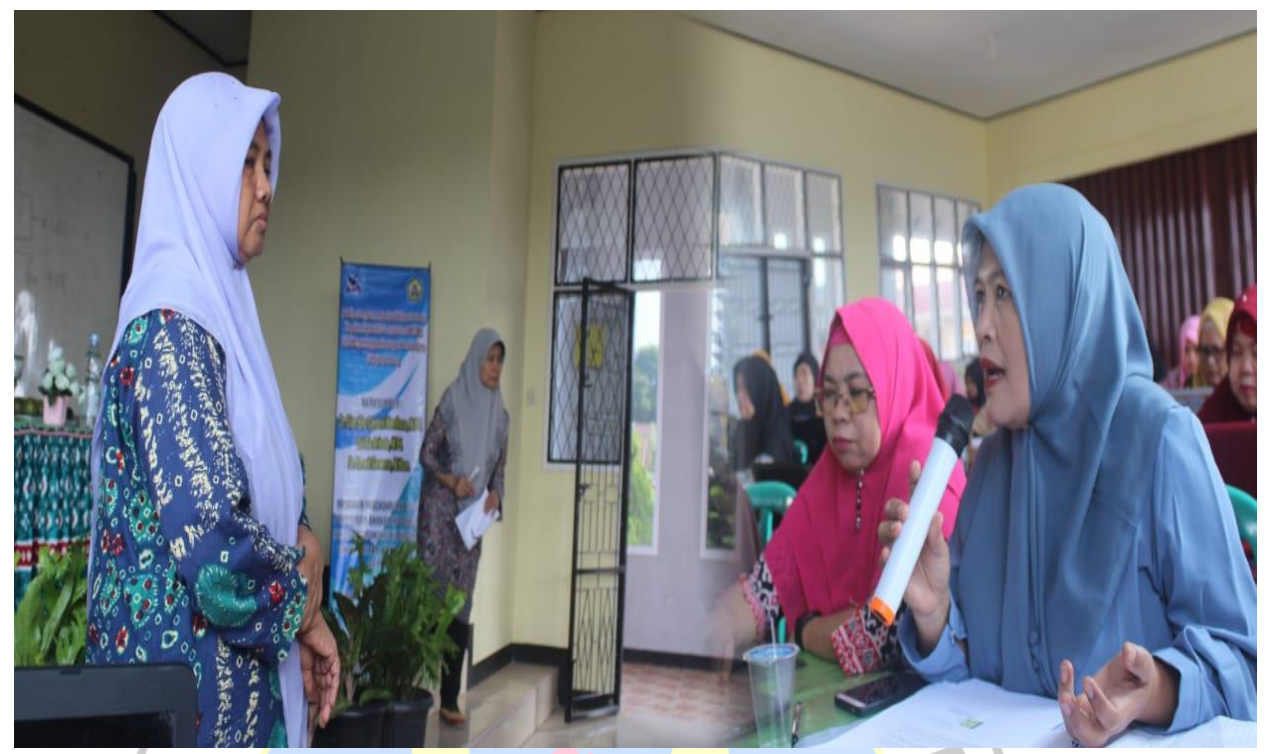

\section{Gambar 4. Foto pada saat pelaksanaan kegiatan}

Gambar 3 menunjukkan kegiatan pengabdian sedang dilaksanakan di ruang aula SMPN 1 Rejang Lebong. Data tersebut merupakan data yang lengkap untuk informasi kegiatan pre tes dan post test yang dilaksanakan pada saat kegiatan pengabdian (9 November 2019) di Ruang Seni (Aula) SMPN 1 yang dihadiri oleh Kepala Dinas Rejang Lebong (Kabid Pembinaan Ketenagaan bersama staf dua orang), Kepala Sekolah dan Tenaga pengabdi 3 orang (FKIP Universitas Bengkulu). Kegiatan Pengabdian dimulai pada pk. 08.00 sampai dengan 16.00. Peserta Kegiatan Pengabdian Program Magister S-2 Pendidikan Bahasa Indonesia dari MGMP Guru Bahasa Indonesia (SMP dan SMA) Negeri yang ada di Kota Rejang Lebong Provinsi Bengkulu. Data yang berhasil dianalisis 40 lembar jawaban dari kegiatan pre test dan post test 45 lembar jawaban dari 50 peserta yang direncanakan. Kegiatan pengabdian diampu oleh 3 tenaga pengabdi. Data pre test dan post test dijaring dari 5 pertanyaan berbentuk esay dan dirumuskan berdasarkan kebutuhan.

Daftar pertanyaan yang dirumuskan untuk pre test dan post adalah lima (5) jenis soal HoTs yang berbentuk essay dengan kemungkinan subyek pengabdian menjawabnya secara terbuka. Model pertanyaan yang dimaksudkan menggunakan perintah menjawab soal (Jawablah Pertanyaan Berikut dengan Menulis Jawaban Bapak dan Ibu di Lembar Jawaban yang sudah Tersedia). Selanjutnya, soal yang dimaksud adalah; (1) Bagaimanakah konsep HOTs yang bapak dan ibu ketahui? (2) Bagaimanakah karakteristik soal-soal HOTs yang sudah bapak dan ibu ketahui? (3) Bagaimanakah komentar Bapak dan Ibu terhadap soal berikut...apakah soal berikut sudah termasuk soal soal HOTs? Andai menurut bapak dan Ibu sudah Hots berikan alasannya dan andai belum HOTs berikan juga alasannya.

\section{Soal-soal yang dimaksudkan adalah,}

(a) Bacalah paragraf berikut dengan saksama!

Novel ini menceritakan Keke, seorang gadis yang cukup beruntung karena lahir dari keluarga yang sangat berada, memiliki dua orang kakak laki-laki yang bernama Chika dan Kiki, orang tua yang sangat menyayanginya walau sudah bercerai, dan juga Pak Yus, ajudan sang Ayah. Selain itu, Keke juga dikelilingi enam sahabat karib yang selalu setia serta menemaninya dan 
hidupnya pun semakin lengkap dengan kehadiran seorang kekasih yang juga begitu menyayanginya, yaitu Andy.

Kutipan tersebut merupakan bagian dari teks ulasa yang berupa;

(1) Evaluasi, (2) rangkuman, (3) orientasi, (4) pendahuluan, dan (5) penafsiran

(b) Bacalah paragraf berikut dan jawablah sesuai petunjuk yang tersedia

Banyak warga Indonesia yang tinggal di negara lain, seperti Amerika Serikat, Inggris, Jerman, dan negara lainnya. Mereka memilih jauh dari tanah airnya demi pekerjaan, studi, bisnis, karier, dan alasan lainnya. Meskipun demikian, jauh dari tanah air tidak berarti terputus silaturahmi dan tidak peduli terhadap permasalahan bangsanya. Untuk mengobati kerinduan pada tanah air, mereka memprakarsai acara-acara yang bernuansa Indonesia. Mereka secara leluasa berbahasa Indonesia, menyajikan makanan khas daerah masing-masing, dan pertunjukan seni daerahnya. Cerita tersebut memiliki hubungan dengan perwujudan fungsi bahasa Indonesia sebagai bahasa nasional, kecuali ....

(1) Lambang identitas nasional

(2) Lambang kebanggaan kebangsaan

(3) Alat penghubung antarwarga, antardaerah, dan antarbudaya

(4) Sebagai bahasa pengantar dalam dunia pendidikan

(5) Pemersatu lapisan masyarakat: sosial, budaya, suku bangsa, dan bahasa

(c) Dalam perjalanan menuju lokasi Festifal Seni di Jepang, saya melihat tulisan besar. Tulisan ini terus terang menggelitik imajinatif dan pikiran saya. Saya bertanya pada teman apa arti "Osama". Ternyata berarti raja. Jepang memang mempunyai beberapa obyek wisata menarik. Perbaikan kata-kata tidak baku dalam paragraf tersebut adalah

(1) festifal, imaji, obyek

(2) festival, imajinasi, objek

(3) pestipal, imaji, objek

(4) festival, imajinăsi, obyek

(5) festifal, imajinasi, objek

1. Bagaimanakah penjelasan tentang kegiatan berpikir kritis sangat penting untuk menguasai capaian berpikir tingkat tinggi/HOTs

2. Bagaimanakah indikator berpikir kritis yang merupakan salah satu ciri soal-soal HOTs?

Ruangan pengabdian sangat representatif, tertatat rapi, setiap meja diberi taplak dan pencahayaan sangat memadai. Ruangan sangat memadai untuk kapasitas 50 peserta. Untuk presentasi tersedia LCD, listrik, papan tulis. Konsumsi berupa kudapan kue kotak yang beriisi 3 kue basah dan kue roti. Transportsasi peserta tersedia dan sambutan penyelenggara sangat baik (Kepala Dinas Pendidikan Dan Kebudyaan Hadir). Hal ini dibuktikan dengan foto bersama pengabdi (Gambar 1) dan kita disiapkan peserta sebanyak 50 orang dengan rincian kegiatan, sambutan Kepala dinas dan pembacaan doa serta ramah tamah dengan pihak dinas dan dilanjutkan dengan kegiatan pre test , pemberian materi dan post test.

Materi pengabdian sangat sesuai dengan judul pengabdian, kebutuhan guru dan kurikulum yang berlku menjelang abad 21 (K-13). Peserta mengikuti kegiatan pengabdian dengan sangat antusias (terbukti ketika diberi pre test dikerjakan) kemudian mengikuti pelatihan atau kegiatan pengabdian selama hampir 10 jam dan mengerjakan soal soal post test (foto-foto kegiatan pengabdian karena keterbatasan halaman secara sampling ada di gambar 3).

Pelaksanaan kegiatan pengabdian ini dievaluasi dengan paduan atau form evaluasi yang terdiri dari 11 pertanyaan dan diberikan secara acak kepada panitia. Pertanyaan yang dimaksud adalah; (1) Apakah ruangan pelatihan representatif untuk kegiatan pelatihan, (2) Apakah tersedia prasarana yang cukup untuk kegiatan pelatihan (fotokopi ppt, LCD, pencahayaan cukup, papan tulis, dan Banner Kegiatan Pengabdian, (3) Apakah tersedia transport untuk peserta pelatihan, (4) Bagaimana sambutan pihak penyelenggara terhadap kegiatan pelatihan, (5) Bagaimanakah kesan para peserta terhadap penyelenggaraan pelatihan, (6) Bagaimanakah kesan para peserta terhadap penyelenggaraan pelatihan

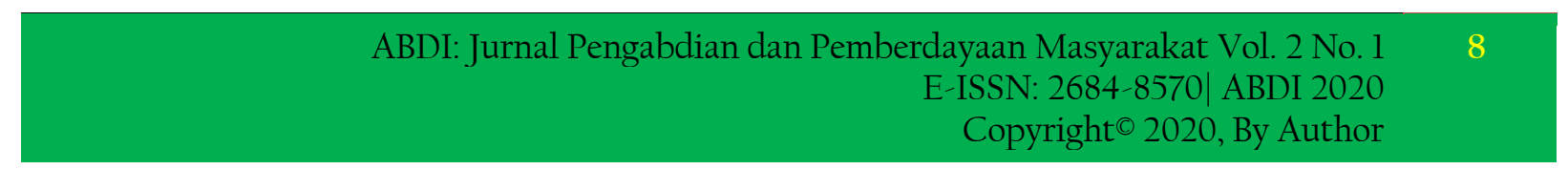


(dan nara sumber), (7) Materi yang disampaikan apakah sesuai dengan judul, (8) Bagaimana peerta mengikuti pelatihan, (9) Bagaimanakah kondisi peserta pada saat melaksanakan pretest, dan (10) Bagaimanakah effektivitas waktu yang digunakan oleh nara sumber pada saat pelatihan.

Selanjutnya kegiatan pengabdian dievaluasi juga oleh tim pengabdi yang terdiri atas 3 orang dengan menggunakan form pengamatan pada saat kegiatan pengabdian. Kegiatan pelaksanaan pengabdian ini dievaluasi dengan form evaluasi kegiatan pengabdian. Evaluasi pelaksanaan kegiatan pengabdian menggunakan form evaluasi kegiatan pengabdian yang dipandu oleh 5 pertanyaan. Lima pertanyaan yang dimaksudkan adalah; (1) Bagaimanakah pelatih (Tim Pelatih) menyampaikan tujuan kegiatan pelatihan dengan baik, (2) Bagaimanakah pelatih mendiskusikan materi pelatihan selam kegiatan pelatihan, (3) Bagaimanakah indikator peserta memahami materi kegiatan?, (4) Bagaimanakah cara peserta mengajukan pertanyaan? dan (5) Bagaimanakah peserta memahami materi pelatihan?

\section{Hasil Pengabdian}

Hasil analisis data kegiatan pengabdian yang dilaksanakan ternyata menunjukkan hasil yang sangat effektif. Hal ini ditunjukkan oleh perubahan perilaku subyek pada saat sebelum pelatihan dan sesudah mengikuti pelatihan. Kondisi ini didukung oleh hasil analisis data yang dikumpulkan pada saat sebelum pelatihan (pre test), dan sesudah pelatihan (post test). Kegiatan pengambilan data ini dirancang akan diikuti oleh 50 subyek pelatihan, namun yang aktif mengikuti kegiatan pengisian instrumen hanya 40. Kesepuluh subyek yang lain dalam kondisi masih di luar ruangan karena terlambat atau ada urusan lain karena mengurus siswa yang masih mengikuti kegiatan ekstra kurikuler.

Berdasarkan hasil analisis data yang dikumpulkan dengan instrumen yang dikumpulkan pada saat pre test dan post test tergambar bahwa ada perubahan perilaku subyek ketika sebelum mengikuti kegiatan pengabdian dan pada saat kegiatan pengabdian berakhir. Perubahan perilaku yang dimaksudkan tampak pada hasil analisis data yang dilakukan dan tergambar pada tabel 1 berikut.

\section{Tabel 1. Hasil uji t paired nilai pre test dan post test}

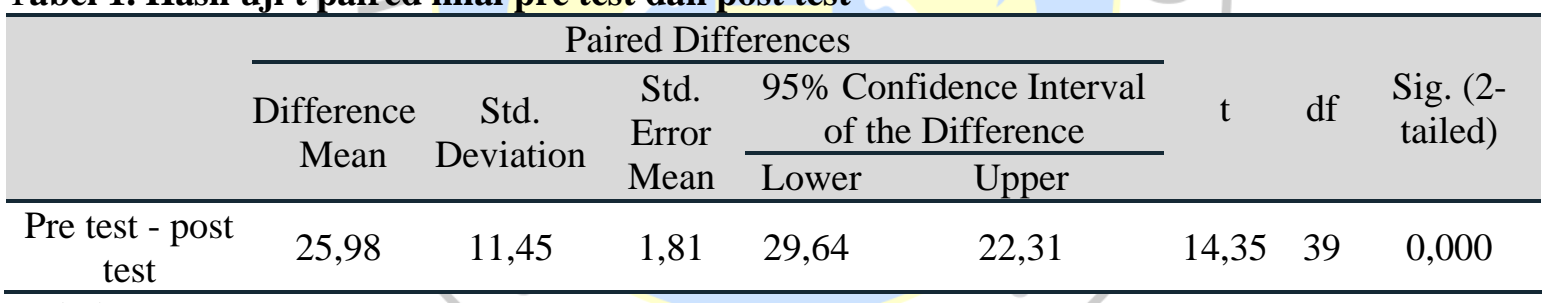

t-tabel $5 \%=1,98$

Pada Tabel 1 ini digambarkan, bahwa nilai rata-rata jawaban intrumen oleh subyek kegiatan pengabdian 2019 pada saat pre test dan post test. Nilai yang terepresentasi pada saat pre test sebesar 46,63 lebih rendah jika dibandingkan dengan rata-rata nilai jawaban intrumen pada post test oleh Subyek yaitu 72,60. Hasil uji t menunjukkan bahwa nilai $\mathrm{P}(\mathrm{T}<=\mathrm{t})$ one-tail sebesar 0,00 . Hal tersebut menunjukkan bahwa nilai pre test berbeda nyata dengan nilai post test karena nilai $\mathrm{P}(\mathrm{T}<=\mathrm{t})$ one-tail lebeih rendah dari taraf 5\% (0,05). Dengan demikian materi yang telah terserap oleh Subyek signifikan dengan kebutuhan Subyek dan ada perubahan perilaku yang ditunjukkan oleh jawaban pada saat pre test dan post test yang signifikan

\section{Kesimpulan}

Kegiatan pengabdian ini dilaksanakan dengan prinsip kolaboratif antara Program Magister S-2 Pendidikan Bahasa Indonesia dengan Subyek kegiatan pengabdian dan jajaran terkait (Dinas Pendiidikan Kabupaten Rejang Lebong, serta guru guru SMPN/SMAN Rejang Lebong). Di samping itu pihak pengabdi menyebarkan instrumen keterpahaman materi. Hal ini bermanfaat untuk merancang kegiatan pengabdian yang akan dilaksanakan pada periode berikutnya. Di samping itu, effektivitas materi pengabdian dipahami oleh subyek pengabdian yang terepresentasi dari nilai rata- 
rata jawaban intrumen oleh responden pada pre test dan post test. Nilai yang terepresentasi pada saat pre test sebesar 46,63 lebih rendah jika dibandingkan dengan rata-rata nilai jawaban intrumen pada post test oleh Subyek yaitu 72,60. Hasil uji t menunjukkan bahwa nilai $\mathrm{P}(\mathrm{T}<=\mathrm{t})$ one-tail sebesar 0,00. Hal tersebut menunjukkan bahwa nilai pre test berbeda nyata dengan nilai post test karena nilai $\mathrm{P}(\mathrm{T}<=\mathrm{t})$ one-tail lebeih rendah dari taraf 5\% $(0,05)$. Dengan demikian materi yang telah terserap oleh Subyek signifikan dengan kebutuhan Subyek dan ada perubahan perilaku yang ditunjukkan oleh jawaban pada saat pre test dan post test yang signifikan.

\section{Daftar Pustaka}

Al-Maamari, F. (2016). Community of assessment practice or interests: The case of EAP writing assessment. Indonesian Journal of Applied Linguistics, 5(2), 272-281. https://doi.org/10.17509/ijal.v5i2.1351

Anderson, L. W., D.R, Krathwohl., P.W, Airasian., K.A, Cruikshank., R.E, Mayer., \& P.R, P. (2001). A Taxonomy for Learning, Teaching, and Assissing: A Revision of Bloom's Taxonomy of Educational Objectives. New York: Longman.

Brookhart, S. M. (2010). How to Assess Higher-Order Thinking Skill in Your Classroom No Title. Virginia: ASCD.

Browne, N. \& Stuart, K. M. (2015). Pemikiran Kritis Panduan untuk Mengajukan dan Menjawab Pertanyaan Kritis. Jakarta: PT Indeks.

Fernandes, R., Vidya Putra, E., \& Muspita, R. (2019). Optimalisasi Institusi Pendidikan Sebagai Upaya Pengendalian Hoax. ABDI: Jurnal Pengabdian Dan Pemberdayaan Masyarakat, 1(1), 16-20. https://doi.org/10.24036/abdi/vol1-iss1/2

Kurniati, D., Harimukti, R., \& Jamil, N. A. (2016). Kemampuan Berpikir Tingkat Tinggi Siswa Smp Di Kabupaten/Jember Dalam Menyelesaikan Soal Berstandar Pisa. Jurnal Penelitian dan Evaluasi Pendidikan, 20(2), 142. https://doi.org/10.21831/pep.v20i2.8058

Leagan, P. (1962). Extension Education for Community Development dalam Extension Education for Community Development. New Deihl: Directorate of Extension Ministry of Food and Agriculture, Government of India.

Muspita, R., Efrina, E., Fernandes, R., Putera, A. S., \& Mahdi, A. (2019). Optimalisasi Kompetensi Guru Sekolah Luar Biasa Dengan Penerapan Teknik Manual Brewing dalam Penyeduhan Kopi. ABDI: Jurnal Pengabdian Dan Pemberdayaan Masyarakat, 1(2), 88-94. https://doi.org/10.24036/abdi/vol1-iss2/31

Norris, S. P, \& Ennis, R. H. (1989). Evaluating critical thinking. Pacific Grove, CA. Critical Thinking Press \& Software.

Winahyu, A. . (2019). Hasil PISA 2018, Kemampuan Siswa IndonesiaTurunle. Koran Humaniora Edisi Terbit 4 Desember 2019. 